\title{
Isotope and Chemical Methods in Support of the U.S. Geological Survey Science Strategy, 2003-2008
}

\section{Background}

Principal functions of the Mineral Resources Program are providing information to planners and decision-makers related to mineral deposits on federal lands and predicting the environmental consequences of the mining or natural weathering of those deposits. Performing these functions requires that predictions be made of the likelihood of undiscovered deposits. The predictions are based on geologic and geoenvironmental models that are constructed for the various types of mineral deposits from detailed descriptions of actual deposits and detailed understanding of the processes that formed them. Over the past three decades the understanding of oreforming processes has benefited greatly from the integration of laboratory-based geochemical tools with field observations and other data sources. Under the aegis of the Evolution of Ore Deposits and Technology Transfer Project (EODTTP), a five-year effort that terminated in 2008, the Mineral Resources Program provided state-of-the-art analytical capabilities to support applications of several related geochemical tools.

In addition to advancing the understanding of the Nation's mineral resources, the EODTTP also transferred geochemical technology to other highpriority investigations in the biologic, hydrologic, and geologic sciences. The rationale for the technology transfer was outlined by the U.S. Geological Survey (USGS) Science Strategy Team in their 2007 publication "Facing tomorrow's challenges: USGS science in the coming decade" which recommends that,

\section{". . . the USGS leverage its} talents and skills to undertake comprehensive and integrated studies that examine the Earth as a system including atmosphere, biosphere, hydrosphere, and lithosphere."
The analytical capabilities and scientific approaches developed within the Evolution of Ore Deposits and Technology Transfer Project have wide applicability within Earth-system science. For this reason the project laboratories and staff represented a valuable catalyst for interdisciplinary collaborations of the type that must be formed in the coming years to meet the United State's natural-resource and natural-science information needs.

\section{Project Laboratories}

Project laboratories make use of commercially-available analytical instruments that are modified by project scientists to meet specific research needs. The laboratories are supervised and operated by experienced scientists with strong backgrounds in their fields of specialization. An emphasis is placed on developing new conceptual approaches and on integrating information from several different types of geochemical analysis in order to maximize insight into complex natural systems. The development of new instrumentation, new analytical methods, and new conceptual approaches has become routine and has led to groundbreaking research results in several scientific areas. The high level of innovation within EODTTP has attracted graduate student volunteers, post-doctoral fellows, and visiting professors working on studies that support USGS science goals. The project has also recruited several young scientists through the Mendenhall Fellow program, which represents an important vehicle for replenishing the USGS research staff.
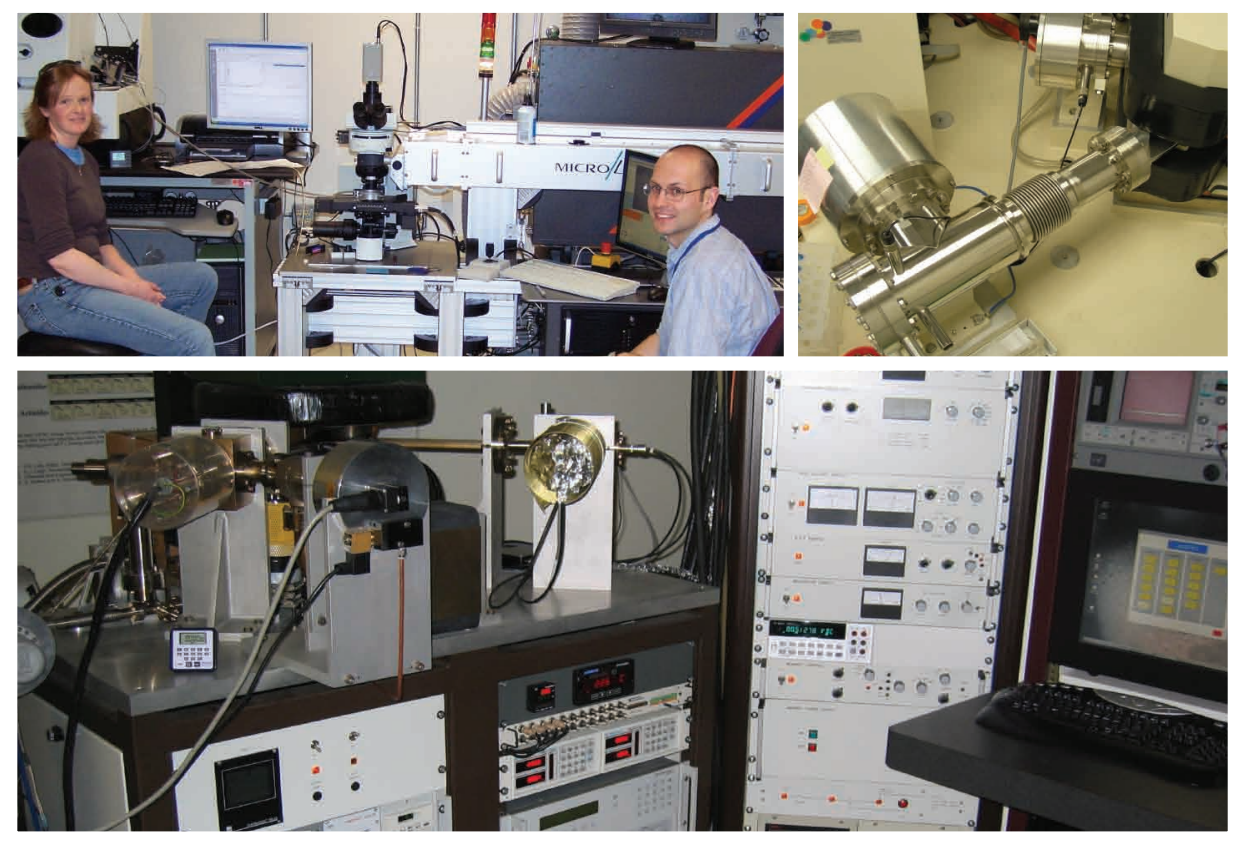

Figure 1. Analytical equipment housed in laboratories supported by the Evolution of Ore Deposits and Technology Transfer Project: laser ablation inductively coupled plasma mass spectrometer in the single fluid inclusion laboratory (top left), gas source magnetic sector mass spectrometer in the stable isotope laboratory (top right), magnetic sector mass spectrometer in the noble gas and active gas laboratory (bottom). 


\section{There are four project laboratories}

1. The Stable Isotope Laboratory provides analyses of the isotopic compositions of the elements carbon, hydrogen, nitrogen, oxygen, and sulfur in a wide range of solid, liquid, and gaseous samples.

2. The Noble Gas and Active Gas Laboratory provides analyses of the concentrations and isotopic compositions of helium, neon, argon, krypton, and xenon and the concentrations of hydrogen, methane, carbon dioxide, nitrogen, and many other gas species in solid, liquid, and gaseous samples.

3. The Single Fluid Inclusion Laboratory provides analyses, by laser ablation, of the concentrations of metals and other cations in individual fluid and solid inclusions that were trapped in crystals during mineral formation in different geologic environments.

4. The Fluid Inclusion Solute Chemistry Laboratory provides analyses of the concentrations of 24 anions and cations in tiny amounts of water liberated from mineral fluid inclusions.

\section{List of Representative Studies}

In its five-year lifetime the Project has supported a large number of studies spanning a broad scientific spectrum. Table 1 lists representative studies grouped according to the six strategic science directions that were outlined by the USGS Science Strategy Team ("Facing tomorrow's challenges: USGS science in the coming decade," 2007). Virtually all the studies were collaborative efforts, and in many cases they were also interdisciplinary, involving scientists from other government agencies, academic research groups, or private industry. Collaborating institutions are indicated in table 1. A forthcoming circular, which contain summaries of these and other studies and a complete list of Evolution of Ore Deposits and Technology Transfer Project publications, will be published in the near future.

\section{A Synopsis of Selected Project Results}

The project was highly successful in its objective of applying innovative geochemical techniques and approaches to important science issues in each of the six strategic science directions. In studies related to mineral resources, important advances were made in understanding ore formation, particularly with respect to sediment-hosted deposits and magmatichydrothermal deposits which represent our primary sources of lead, zinc, and copper, and important sources of several other metals and non-metal commodities. The results of these studies are currently being integrated with ore deposit models that together will form the basis of upcoming USGS assessments of the country's mineral resources as well as the resources of other regions that are important for the global supplies of particular mineral commodities.

In studies of ecosystems, geochemical methods were invaluable in the determination of the diets and feeding behavior of animal populations that have been, or currently are, in decline. Study subjects included brown bears, grizzly bears, sea lions, and wolves in locations where the animals influence or are influenced by commercial or recreational fishing, and in national parks where wildlife constitute a biological resource. In multiyear studies or in studies where archived samples of animal tissues were available, geochemical tools yielded insights on the ways in which ecosystems have changed. The results of these studies indicated that spawning fish play an integral role in food webs located far from coastal areas.

Table 1. Representative studies supported by the Evolution of Ore Deposits and Technology Transfer Project, grouped according to the six strategic science directions that were enumerated by the U.S. Geological Survey (USGS) Science Strategy Team.

Strategic Science Direction

1. Ecosystems and

Ecosystem Change

\section{Environment and Human Health} 3. Water Census of the
United States

Title of Study

Collaborators

Grizzly Bears in the Greater Yellowstone Ecosystem

Biogeochemical Perspective on Food Webs in a Prairie Wetland

Nutritional Stress as a Possible Cause for Declines on the Western Steller Sea Lion

Nutritional Ecology of Denali Wolves

Wetlands Ecosystems, Migratory Shorebirds, and Isotope Geochemistry

Anthropogenic Sulfate in Natural Waters

Cyanide in Leach Wastes at Gold Mines

Geochemical Reconnaissance of the Arbuckle-Simpson Aquifer, South-Central Oklahoma

Noble Gas Geochemistry of the Edwards Aquifer, South-Central Texas
Interagency Grizzly Bear Study Team, National Park Service, Washington State University Bear Center

USGS Biological Resources Discipline, South Dakota State University

Alaska Department of Fish and Game, National Oceanic and Atmospheric Administration

USGS Alaska Science Center, National Park Service

USGS Biological Resources Discipline

Colorado Groundwater Resource Service Inc.

Pinson Mining Company, Barrick Gold Corporation, Newmont Mining Corporation, Shell Oil Company, Getchell Gold Corporation, Onstream Resource Managers, U.S. Environmental Protection Agency Region 6, USGS Columbia Environmental Research Center, RETEC Group Inc.

Oklahoma Water Resources Board, National Park Service, USGS Water Science Center-Oklahoma City, USGS National Research Program

Edwards Aquifer Authority, San Antonio Water System, USGS Water Science Center-San Antonio 


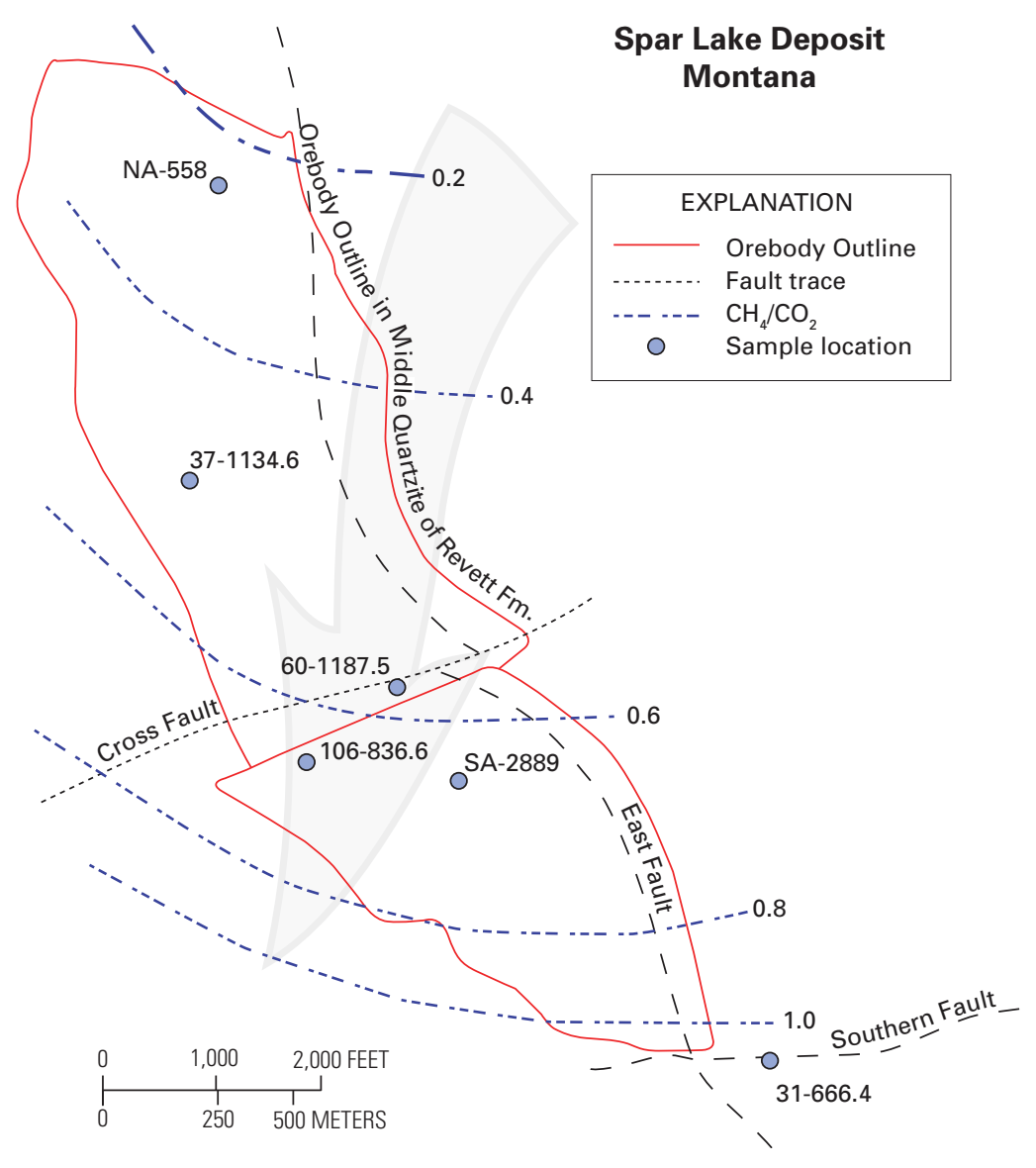

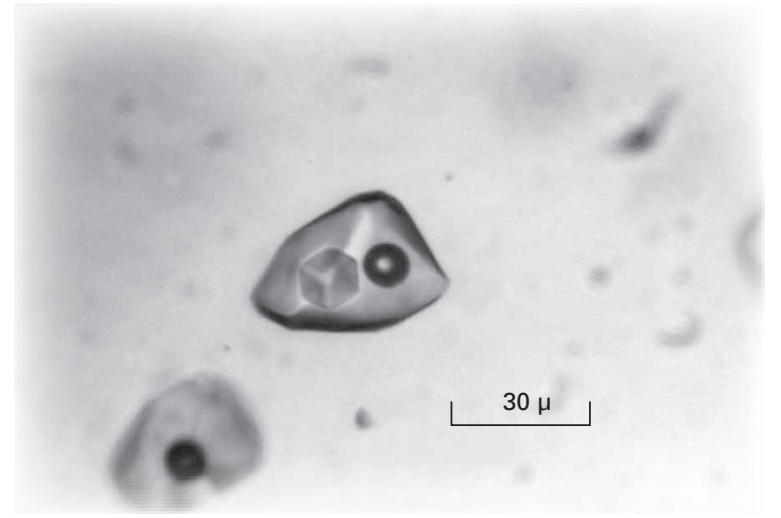

Figure 2. Microscopic inclusion in quartz from a sedimentary rock collected from the Spar Lake copper-silver deposit in Montana (top). The inclusion consists of a solid crystal and a vapor bubble surrounded by water-rich liquid. Chemical analysis of the vapor bubble in many samples of this type revealed the map-view spatial patterns that are shown in the bottom figure. The pattern is evidence that the ores formed where metalliferous brines flowing through an aquifer (flow direction is indicated by arrow) encountered a natural gas reservoir. Understanding the genesis of the Spar Lake deposit will help U.S. Geological Survey scientists advise land managers on the potential for economic accumulations of copper and silver elsewhere in western Montana and in other areas.

Table 1. Representative studies supported by the Evolution of Ore Deposits and Technology Transfer Project, grouped according to the six strategic science directions that were enumerated by the U.S. Geological Survey (USGS) Science Strategy Team—Continued.

\section{Strategic Science Direction} and Resilience ment

\section{Climate Variability} and Change

6. Energy and Minerals for America's Future
Colorado Alpine Glaciation and Climate History

Brown Bears in the Kuskokwim Mountains, Southwest Alaska

\section{Title of Study}

Landslide Hazards at Mt. Rainier Related to Hydrotherma Alteration

Fault Slip Rates of the West Salton Detachment System: Input for Earthquake Hazard Assessment

Lake Studies in Support of Global Change Program

Spar Lake Copper-Silver Deposit, Montana: Ore-Forming Processes Revealed in Fluid Inclusion Analyses

Natural Destruction of an Alunite Deposit at Big Rock Candy Mountain, Marysvale, Utah

Banded Alunite as an Indicator of Ore Forming Magmatic Hydrothermal Processes

Giant Deposits of Zinc and Lead in the Western Brooks Range of Alaska
Collaborators

USGS Volcano Hazards Program, National Park Service

USGS National Mapping Program

USGS Tropical and Arid Regions Climate Project, Lawrence Livermore National Laboratory, University of Nevada, University of Southern California

USGS Water Resources Discipline, USGS Earth Surface Dynamics Program, New Mexico Bureau of Mines and Geology, Paul Scherrer Institute of Particle Physics-Switzerland, Dalhousie University

U.S. Fish and Wildlife Service

Teck Cominco Limited, USGS Energy Program, Bureau of Land Management 
Figure 3. Grizzly bear eating cow parsnip in Yellowstone National Park (right). Other food sources for bears in the Greater Yellowstone Ecosystem include nut-bearing cones from white bark pine trees (lower left) and cutthroat trout (lower right). Data from controlled feeding experiments at the Washington State University Bear Center show that the mercury content of bear hair reflects the amount of mercury ingested in fish (lower right). Photographs courtesy of Karyn Rode (right), Charles Schwartz (lower left), and U.S. Forest Service (lower right). Graphs (bottom) from Felicetti and others (2004).
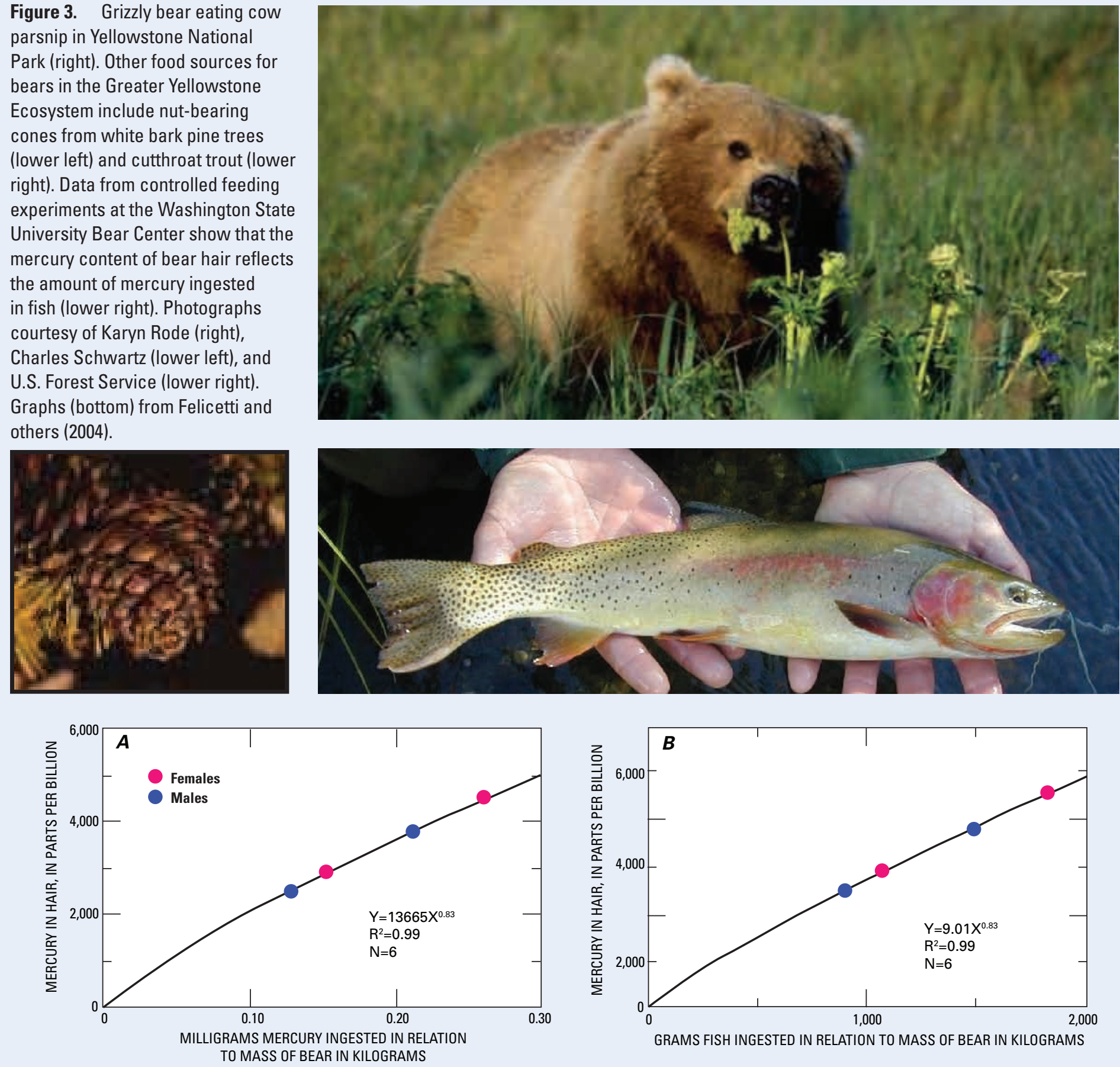

In studies related to environment and human health, isotope and chemical methods were applied to specific chemical species in natural waters that can be harmful to the health of aquatic life and humans. The investigations used stable-isotope compositions to fingerprint the source of harmful chemicals and to identify the processes that supplied them to the natural environment. The sources and fate of solutes can be important for reasons beyond effects on drinking water. For example, elevated concentrations of the sulfate anion can signal acidification of the waters by natural or anthropogenic processes, or can signal salinization of associated soils which can lead to stunted vegetation or low crop yields.

In studies supporting a water census of the United States, multiple geochemical tools were used to determine the origin and distribution of groundwater underlying broad areas of Oklahoma and Texas. This work informed decision makers on matters of current and future water quality and water availability. Key findings were obtained from noble-gasisotope measurements which provided estimates of aquifer replenishment rates and estimates of the rates at which water can be safely withdrawn without depleting the resources.
Contributions to hazard assessment included collaborative studies of landslide potential at active and dormant volcanoes in the Cascade Range and studies of the slip rate along part of the San Andreas fault system in southern California. At Mount Rainier in the Cascade Range evidence of hydrothermal alteration-which can render volcanic edifices landslide-prone-was identified in volcanic products dating back as far as 10,000 years. Important variables in assigning landslide risk were found to be the degree of brecciation of a given volcanic rock unit and its proximity to the volcanic conduit. In a field area on the 

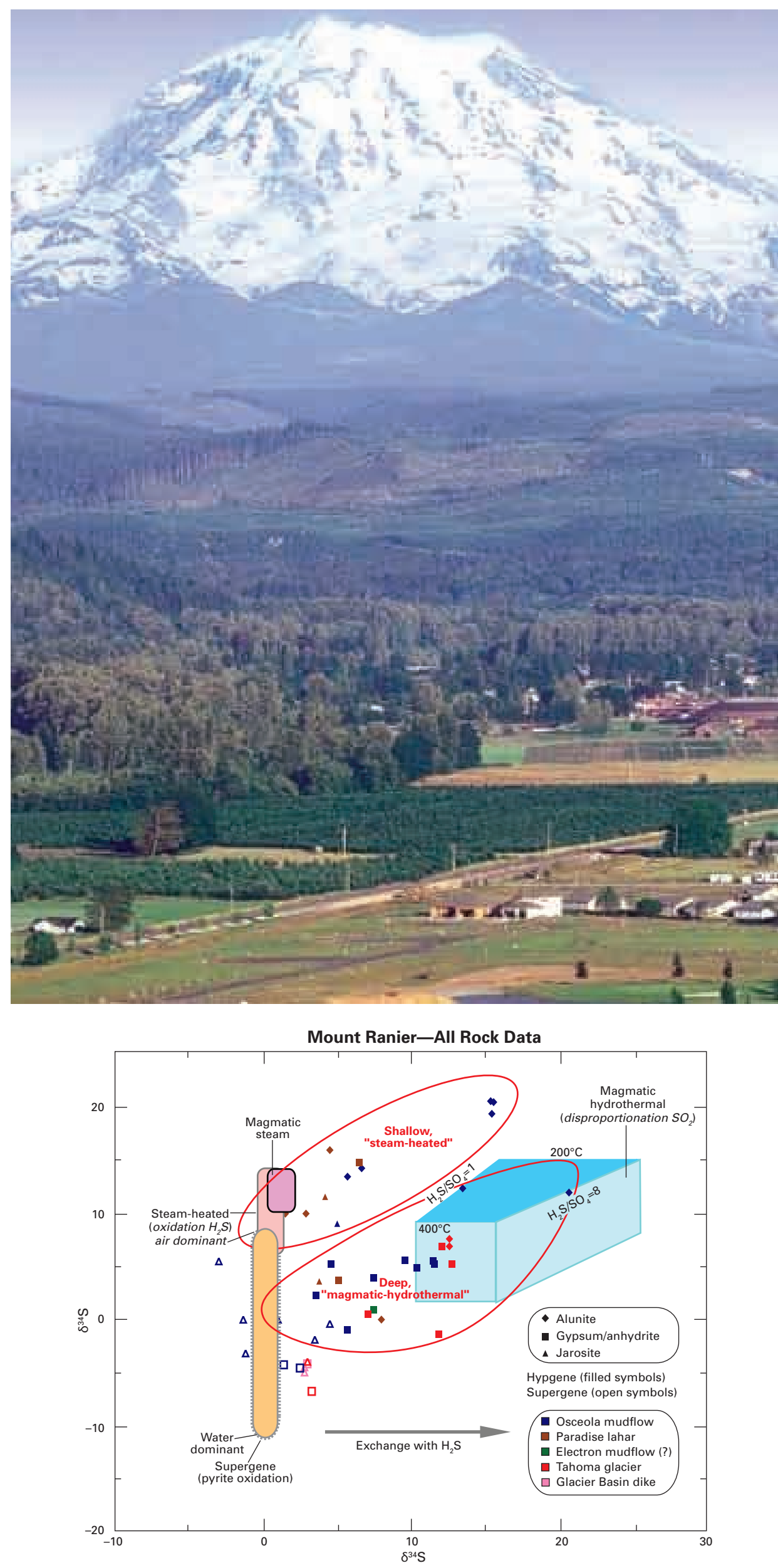

west side of the Salton Trough in southern California, analysis of the cosmic radiation-produced isotopes helium-3 and neon-21 revealed the time interval that was required to displace erosional boulders 24 kilometers in a southerly direction along a strike-slip fault. The average slip rate of the fault, 20 millimeters per year, is a critical parameter in the estimation of accumulated stress and the prediction of the likelihood and probable magnitude of future earthquakes in the region.

Climate variability was documented in different studies that addressed climate change over decadal to millennial time scales. In the Kuskokwim Mountains of Alaska, brown bears were found to rely significantly on spawning salmon for food. A transient decline in salmon returns in the past decade was mirrored by a decline in the growth rate of the bear population suggesting that the viability of the mammals may be indirectly tied to ocean conditions in the North Pacific (for example, the Pacific Decadal Oscillation), which are known from other studies to influence salmon returns. A longer record of climate variability was obtained from a sediment core taken in Pyramid Lake, Nevada, a closed water body that loses water only by evaporation. High resolution oxygen isotope analysis of the core, which contains a continuous record of climate change for the past 8,000 years, suggests that future climate in the western U.S. has the potential for longer lasting and more intense droughts than are reflected in shorter-term instrumental records of climate change.

Figure 4. Mount Rainier volcano (top left), which is located about 100 kilometers southeast of downtown Seattle. Farms and residential development cover the Osceola mudflow which formed in a catastrophic eruption 5,600 years ago and buried an area of about 500 square kilometers. (Left) The isotopic compositions of sulfur $\left(\delta^{34} S\right)$ and oxygen $\left(\delta^{18} 0\right)$ in minerals that were formed by hydrothermal alteration of the flanks of the volcano. The data reveal conditions of formation of the minerals and the source of the hot waters that formed them, information that is used in evaluating the collapse potential of volcanic edifices in the United States and its territories. Photograph courtesy of USGS Cascades Volcano Observatory. 
From a broader perspective, the Project laboratories - and the geochemical approaches that they provide-proved to be highly effective as catalysts for interdisciplinary studies on topics relevant to the current science priorities of the USGS. Key factors that fostered interdisciplinary collaborations were:

- The multiplicity of methods and approaches that are associated with the project,

- The commitment of the Mineral Resources Program to maintain the laboratories as highly capable state-of-the-art facilities, and

- The willingness of project scientists to apply their geochemical expertise to scientific problems that lie outside their traditional areas of research.

-Robert O. Rye, Craig A. Johnson, Gary P. Landis, Albert H. Hofstra, Poul Emsbo, Craig A. Stricker, Andrew G. Hunt, and Brian G. Rusk

\section{Selected Project Publications}

Felicetti, L.A., Schwartz, C.C., Rye, R.O., Gunther, K.A., Crock, J.G., Haroldson, M.A., Waits, L., and Robbins, C.T., 2004, Use of naturally-occurring mercury to determine the importance of cutthroat trout to Yellowstone grizzly bears: Canadian Journal of Zoology, v. 82, p. 493-501.

Hunt, A.G., Lambert, R.B., Landis, G.P., and Waugh, J.R., 2005, Use of helium isotopes to discriminate between flow paths associated with the freshwater/saline water transition zone of the Edwards Aquifer, south-central Texas, in Kuniansky, E.L. (ed.), U.S. Geological Survey Karst Interest Group Proceedings, Rapid City, South Dakota, September 12-15, 2005: U.S. Geological Survey Scientific Investigations Report 2005-5160, p. 42.

Johnson, C.A., Kelley, K.D., and Leach, D.L., 2004, Sulfur and oxygen isotopes in barite deposits of the western Brooks Range, Alaska, and implications for the origin of the Red Dog massive sulfide deposits: Economic Geology, v. 99, p. 1435-1448.

Otton, J.K., Zielinski, R.A., and Johnson, C.A., 2005, Origin of saline soils in the Front Range area north of Denver, Colorado: U.S. Geological Survey Professional Paper 1698, p. 73-87.

Rye, R.O., 2005, A review of the stable-isotope geochemistry of sulfate minerals in selected igneous environments and related hydrothermal systems: Chemical Geology, v. 215, p. 5-36.

\section{For More Information Contact:}

Robert O. Rye

U.S. Geological Survey, MS 963

Denver, CO 80225

Telephone: 303-236-7907

Email: rrye@usgs.gov

Craig A. Johnson

U.S. Geological Survey, MS 963

Denver, CO 80225

Telephone: 303-236-7935

Email: cjohnso@usgs.gov 